\title{
Preliminary characterization of a Moroccan honey with a predominance of Bupleurum spinosum pollen
}

Youssef Elamine, Smail Aazza, Badiâa Lyoussi, Maria Dulce Antunes, Letícia M Estevinho, Ofélia Anjos, Mafalda Resende, Maria Leonor Faleiro \& Maria Graça Miguel

To cite this article: Youssef Elamine, Smail Aazza, Badiâa Lyoussi, Maria Dulce Antunes, Letícia M Estevinho, Ofélia Anjos, Mafalda Resende, Maria Leonor Faleiro \& Maria Graça Miguel (2018) Preliminary characterization of a Moroccan honey with a predominance of Bupleurum spinosum pollen, Journal of Apicultural Research, 57:1, 153-165, DOI: 10.1080/00218839.2016.1265759

To link to this article: https://doi.org/10.1080/00218839.2016.1265759

\section{曲 Published online: 19 Jan 2017.}

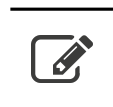

Submit your article to this journal $\lceil\pi$

Џلll Article views: 188

View Crossmark data ¿

Citing articles: 3 View citing articles $\longleftarrow$ 


\title{
ORIGINAL RESEARCH ARTICLE
}

\section{Preliminary characterization of a Moroccan honey with a predominance of Bupleurum spinosum pollen}

\author{
Youssef Elamine ${ }^{\mathrm{a}} \mathbb{D}$, Smail Aazza ${ }^{\mathrm{a}}$, Badiâa Lyoussi ${ }^{\mathrm{a}}$, Maria Dulce Antunes ${ }^{\mathrm{b}}$, Letícia M Estevinho ${ }^{\mathrm{c}, \mathrm{d}}$, Ofélia Anjos ${ }^{\mathrm{e}, \mathrm{f}, \mathrm{g}}$ (D), \\ Mafalda Resende ${ }^{\mathrm{h}}$, Maria Leonor Faleiro' (i) and Maria Graça Miguel ${ }^{\mathrm{b} *}$ (1)
}

${ }^{a}$ Laboratory of Physiology-Pharmacology-Environmental Health, Faculty of Sciences Dhar El Mehraz, University Sidi Mohamed Ben Abdallah, Fez, Morocco; ${ }^{b}$ FCT, Universidade do Algarve, Faro, Portugal; ' Escola Superior Agrária, Instituto Politécnico de Bragança, Apartado Bragança, Portugal; ${ }^{d}$ Centre of Molecular and Environmental Biology, University of Minho, Braga, Portugal; ${ }^{\mathrm{e}}$ Instituto Politécnico de Castelo Branco, Castelo Branco, Portugal; ${ }^{f}$ CEF, Universidade de Lisboa, ISA, Lisboa, Portugal; ${ }^{g}$ Centro de Biotecnologia de Plantas da Beira Interior, Castelo Branco, Portugal; ${ }^{h}$ CATAA - Centro de Apoio Tecnológico Agro-Alimentar de Castelo Branco, Zona Industrial de Castelo Branco - Rua A, Castelo Branco, Portugal; ${ }^{i} F C T$, Center for Biomedical Research, Universidade do Algarve, Faro, Portugal

(Received 29 April 2016; accepted 18 November 2016)

\begin{abstract}
Honey with Bupleurum spinosum (zandaz) as a main pollen source has not been the subject of previous detailed study. Therefore, twelve Moroccan samples of this honey were subjected to melissopalynological, physicochemical and microbiological quality characterization, as well as antioxidant activity assessment. From a quality point of view, almost all samples were within the limits established by Codex Alimentarius, and/or the European legislation. All samples presented predominance of B. spinosum pollen (more than 48\%). Relatively high levels of trehalose $(1.3-4.0 \mathrm{~g} / 100 \mathrm{~g})$ and melezitose $(1.5-2.8 \mathrm{~g} / 100 \mathrm{~g})$ were detected. Those sugars, not common in monofloral honeys, could be used as an important factor to discriminate zandaz honey. Flavonoid content correlated positively with the honey color, melanoidin and polyphenol content, and negatively with the $I_{50}$ values of scavenging $A B T S$ (2,2'-azino-bis(3-ethylbenzothiazoline-6-sulfonic acid) free radicals, while proline amount correlated negatively with $I C_{50}$ values of nitric oxide scavenging activity and chelating power. This correlation supports the use of anti-oxidant activities as important variables for PCA (principal component analysis). Both components explained $70 \%$ from the given data, and showed certain homogeneity upon analyzed samples independent of the region, suggesting the importance of B. spinosum nectar in the resulting honey characteristics.
\end{abstract}

\section{Caracterización preliminar de una miel marroquí con predominio del polen de Bupleurum spinosum}

La miel con Bupleurum spinosum (pendejo) como principal fuente de polen no ha sido objeto de un estudio detallado previo. Por lo tanto, doce muestras marroquíes de esta miel fueron sometidas a una caracterización melisopalinológica, físico-química y microbiológica, así como a la evaluación de su actividad antioxidante. Desde el punto de vista de la calidad, casi todas las muestras estaban dentro de los límites establecidos por el Codex Alimentarius y/o la legislación europea. Todas las muestras presentaron predominio de polen de B. spinosum (más del $48 \%$ ). Se detectaron niveles relativamente altos de trehalosa $(1.3-4.0 \mathrm{~g} / 100 \mathrm{~g})$ y melecitosa $(1.5-2.8 \mathrm{~g} / 100 \mathrm{~g})$. Esos azúcares, no comunes en mieles monoflorales, podrían ser utilizados como un factor importante para discriminar la miel de pendejo. El contenido de flavonoides se correlacionó positivamente con el color de la miel, el contenido de melanoidina y polifenol y negativamente con los valores de IC $_{50}$ de la actividad de barrido de los radicales libres de ABTS (2,2'-azino-bis (3-etilbenzotiazolina-6-sulfónico), mientras que la cantidad de prolina se correlacionó negativamente con los valores de $\mathrm{IC}_{50}$ de la actividad de barrido de ON (óxido nítrico) y el poder quelante. Esta correlación apoya el uso de las actividades antioxidantes como variables importantes para el APC (análisis de componentes principales). Ambos componentes explican el $70 \%$ de los datos obtenidos y muestran cierta homogeneidad en las muestras analizadas independientemente de la región, lo que sugiere la importancia del néctar de $B$. spinosum en las características de la miel resultante.

Keywords: Bupleurum spinosum; Zandaz honey; melissopalynology; physicochemical analysis; antioxidant activity; botanic origin

\section{Introduction}

The floral origin determination of honey is very important in the field of apicultural research, due to its direct link with customer demand. For the purpose of consumer protection, the honey floral origin labeling has been required by the European Community legislation, i.e., Directive EEC/74/409 amended by the Proposal COM/95/0722 (1996).
Melissopalynolgical, sensory and physico-chemical analyzes together are needed for establishing the botanical denomination of a honey, because when considered individually, each one has its own limitations. Regarding melissopalynolgical analysis, whereas some honey types need high percentage of pollen to be considered as monofloral ( $90 \%$ for chestnut honey), for others only $15 \%$ is sufficient to declare their botanical origin 
(e.g., Lavandula spp.) (Gomes, Dias, Moreira, Rodrigues, \& Estevinho, 2010).

Physico-chemical parameters are also important in the determination of the botanical origin of honey and are widely used in routine honey analysis. Persano Oddo et al. (2004) reported that color, electrical conductivity, specific rotation, diastase, acidity, fructose and glucose content have the most important value in discriminating honey origins. In addition, the physicochemical analysis: sugars (de la Fuente, Ruiz-Matute, Valencia-Barrera, Sanz, \& Martínez Castro, 20II); volatile compounds (Bouseta, Scheirman, \& Collin, 1996); phenols (Escriche, Kadar, Juan-Borrás, \& Domenech, 2014); and minerals (Anklam, 1998) amongst others, is largely influenced by honey variability (honey seasonal, geographical variability, among other factors) (Persano Oddo et al., 2004). The use of one cannot be sufficient in itself, and the discriminatory power only increases with the number of parameters used (Persano Oddo et al., 2004).

The whole image of the botanical origin can be established only, when the sensory correspondence is evaluated (Persano Oddo et al., 2004); because this tool can exclude some samples from being characterized as monofloral, based on the other parameters, if some botanic components altering the sensory characteristics are detected (Piana et al., 2004). Nevertheless, sensory evaluation is always linked to inherent subjective factors.

The main goal of the present work is to establish a first screening of melissopalynological and physicochemical characterization and, at same time some, to determine the in vitro antioxidant activity of 12 samples of a Moroccan honey with Bupleurum spinosum as the main pollen source. In Morocco, this honey is called zandaz, zentaz, aguerbaz or airbaz honey, referring to the berbere name of B. spinosum Gouan (Syn. Bupleurum fruticescens subsp. spinosum (Gouan) O. Bolòs \& Vigo) (Figure I(a)). This species can be found in the siliceous high peaks of eastern Anti-Atlas, generally above $2000 \mathrm{~m}$ a.s.l. (Peltier, 1983). Some authors also reported the presence of this species at high altitudes of the High Atlas (above approximately $2900 \mathrm{~m}$ a.s.l.) and in some mountains of the middle Atlas (Nassif \& El Amiri, 20II) where the samples of this study were mainly collected. The flowering period occurs during August-September (Khabbch, Libiad, \& Ennabili, 20I4).

\section{Material and methods}

The twelve honey samples $(n=12)$ were directly purchased from beekeepers and centrifuged upon receipt at the laboratory. In Table I the sample codes, production years, places of collection and their most predominant pollen types are presented.

\section{Chemicals, reagents and equipment}

Culture media were purchased from Biokar, (Paris, France) or Oxoid (Basingstoke, Hampshire, UK); peptone water (Oxoid; Basingstoke, Hampshire, UK); $\mathrm{NaOH}, \mathrm{Na}_{2} \mathrm{CO}_{3}$, sodium phosphate were purchased from Pronalab, Madalena, Portugal; $\mathrm{HCl}$ was purchased from Fisher Scientific UK Ltd.; Loughborough, UK; $\mathrm{KCl}$ was purchased from BHD Prolabo; Leuven, Belgium; acetic acid, ascorbic acid, Folin-Ciocalteu, fuchsin, $\mathrm{KOH}$, methanol, 2-propanol were purchased from Merck KGaA; Darmstadt, Germany; 2,2'-azino-bis(3ethylbenzothiazoline-6-sulphonic acid) (ABTS), ferrozine, $\mathrm{FeSO}_{4}$, gallic acid, NBT, ninhydrine, PMS, proline were purchased from Acros Organics; New Jersey, USA; $\mathrm{AlCl}_{3}$ and anhydride acetic were purchased from Panreac Química, Montcada i Reixac; Barcelona, Spain; catechin was purchased from Fluka. Biochemika. SigmaAldrich; Steinheim, Germany; glucose, fructose, sucrose, maltose, turanose, trehalose, melezitose, were purchased from Sigma Aldrich Chimie $\mathrm{GmbH}$, Riedstr; Steinheim, Germany; $\mathrm{H}_{2} \mathrm{SO}_{4}$, sodium acetate, starch, potassium iodide, $\mathrm{I}_{2}$, sodium nitroprusside (SNP), were purchased from Riedel-de-Haen; Germany; acetic acid was purchased from CHEM-Lab; Belgium; optic micro-
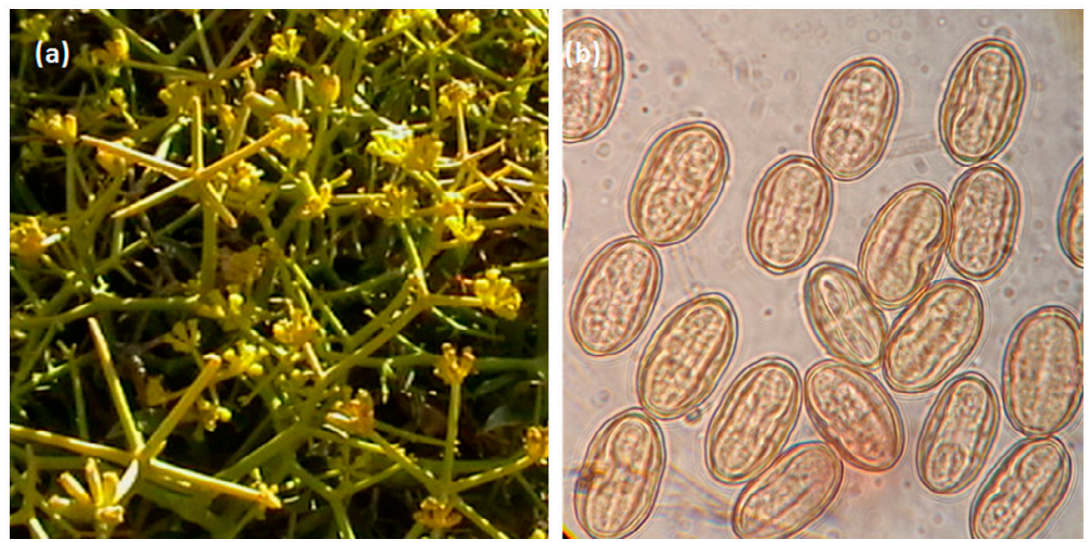

Figure I. (a) Flowers of B. spinosum plant; (b) B. spinosum pollen under microscope (400X). 
Table I. Sample code, places of collection, year of production and the most predominant pollen of twelve B. spinosum honey samples from Morocco.

\begin{tabular}{|c|c|c|c|c|c|c|}
\hline $\begin{array}{l}\text { Sample } \\
\text { code }\end{array}$ & $\begin{array}{l}\text { B. } \\
\text { spinosum } \\
\text { (PP) }\end{array}$ & SP Species (\%) & IMP & MP & $\begin{array}{l}\text { Region } \\
\text { name }\end{array}$ & $\begin{array}{l}\text { Harvest } \\
\text { year }\end{array}$ \\
\hline SI & 58.9 & Opuntia spp. (17.7) & $\begin{array}{l}\text { Epilobium spp. (13.8) + Eragrostis spp. (3.5) + Thymus spp. } \\
(3.0)+\text { Others (3.0) }\end{array}$ & & Ait Bazza & 2011 \\
\hline S2 & 63.0 & Thymus spp. (19.8) & Opuntia spp. (8.6) + Phoenix spp. (8.6) & & Ait Bazza & 2013 \\
\hline S3 & 62.9 & Opuntia spp. (I8.8) & Olea spp. (9.2) + Thymus spp. (4.3) + Others (4.9) & & Ait Bazza & 2013 \\
\hline S4 & 53.7 & & $\begin{array}{l}\text { Cactus spp. (4.4) + Epilobium spp. (13.0) + Eragrostis spp. } \\
(5.9)+\text { Opuntia spp. (I I.2) + Thymus spp. (7.5) + Others (4.4) }\end{array}$ & & $\begin{array}{l}\text { Ait } \\
\text { Bouilloul }\end{array}$ & 2013 \\
\hline S5 & 83.0 & & Olea spp. (7.I) + Opuntia spp. (9.9) & & $\begin{array}{l}\text { Ait } \\
\text { Bouilloul }\end{array}$ & 2013 \\
\hline S6 & 62.4 & Thymus spp. (2I.3) & Eragrostis spp. (6.3) + Phoenix spp. (6.3) + Others (3.7) & & Ait Ali & 2013 \\
\hline S7 & 68.9 & & $\begin{array}{l}\text { Cardus spp. (8.0) + Eucalyptus spp. (4.4) + Olea spp. } \\
(10.4)+\text { Thymus spp. }(8.0)\end{array}$ & & Ait ali & 2012 \\
\hline S8 & 55.6 & Cardus spp. (25.3) & Phoenix spp. (3.I) + Thymus spp. (I I.4) + Others (4.7) & & $\begin{array}{l}\text { Ait } \\
\text { bourais }\end{array}$ & 2011 \\
\hline S9 & 48.8 & $\begin{array}{l}\text { Cardus spp. } \\
(24.5)+\text { Olea spp. } \\
(17.4)\end{array}$ & Phoenix spp. (6.5) & $\begin{array}{l}\text { Others } \\
(2.8)\end{array}$ & Boulemane & 2011 \\
\hline SIO & 7I.I & Cardus spp. (22.2) & Acacia spp. (3.9) + Phoenix spp. (3.9) & & Bouiblane & 2013 \\
\hline SII & 65.0 & Cardus spp. (30.8) & + Others (4.2) & & Bouiblane & 2013 \\
\hline $\mathrm{SI} / 2$ & 56.8 & Cactus spp. (24.2) & Acacia spp. (7.0) + Phoenix spp. (12.0) & & Bouiblane & 2013 \\
\hline
\end{tabular}

Notes: PP - predominant pollen (>45\%); SP - secondary pollen (16-45\%); IMP - important minor pollen (3-15\%); MP - minor pollen (<3\%).

scope (Leitz Messtechnik GmbH; Wetzlar, Germany); HPLC: Dionex ICS3000 equipment; microplate reader (Tecan Infinite M200; Tecan, Austria); potentiometer combined with glass electrode (Thermo Electron Corporation, Orion 3 STAR; USA); analytical balance (Shimadzu, Aux 220; Philippines); electric furnace (Cassel; Portugal); conductivity meter (Thermo Electron Corporation, Orion 3 STAR; USA); Abbe Refractometer (HANNA, HI96860I; Romania); HPLC (Hitachi, LaChrom Elite; Japan).

\section{Melissopalynological analysis}

The analysis of the honey samples' pollen qualitative and quantitative spectrum was performed according to the International Commission for Bee Botany (ICBB), as previously described in detail (Louveaux, Maurizio, \& Vorwohl, 1978). Pollen identification and count were carried out using a light microscope (Leitz Messtechnik GmbH; Wetzlar, Germany) with $400 \times$ and I000X objectives, the latter being used when greater detail was required for the morphological identification. For each honey sample, we counted and analyzed a minimum of 1000 pollen grains. Frequency classes were determined twice for each sample and designated as dominant pollen $(>45 \%$ of a specific pollen type), secondary pollen (16-45\%), important minor pollen (3-15\%) and minor pollen $(<3 \%)$.

\section{Microbiological evaluation}

The microbiological quality of the honey samples was examined by determining the counts of aerobic mesophilic bacteria, Enterobacteriaceae and sulfitereducing Clostridium spp. The counts of aerobic mesophilic bacteria were done using the Plate Count Agar medium as described in the standard NP-4405:2002 (NP-4405:2002, 2002). The determination of Enterobacteriaceae and sulfite-reducing Clostridium spp. were performed according to the standards ISO 21528-2:2004 and ISO 15213:2003, respectively (ISO 21528-2:2004, 2004; ISO I52I3:2003, 2003). Homogenates of $10 \mathrm{~g}$ of each honey sample with $90 \mathrm{ml}$ of peptone water (Oxoid) were subject to decimal dilutions that were inoculated in appropriate medium. The viability counts were done in triplicate.

\section{Physico-chemical analysis}

All measurements described in this section were performed in triplicate, except the sugar content that was performed in duplicate. Results were then expressed as mean $\pm \mathrm{SD}$. The parameters $\mathrm{pH}$, free acidity, lactonic acidity, total acidity, ash content, electrical conductivity, moisture, proline content, diastase activity and HMF content, were assessed following the Harmonized methods of the International Honey Commission (Bogdanov, 2002).

\section{Honey color and melanoidins estimations}

Color was determined by measuring the absorbance of aqueous solutions ( $10 \mathrm{~g}$ of honey in $20 \mathrm{ml}$ of distilled water) at $635 \mathrm{~nm}\left(A_{635}\right)$ in a Shimadzu spectrophotometer (Naab, Tamame, \& Caccavari, 2008). The mm Pfund values and honey color were obtained using the follow- 
ing algorithm, $\mathrm{mm}$ Pfund $=-38.7+371.39 \times A_{635}$. Additionally, honey color was determined by spectrophotometry by calculating net absorbance $\left(A_{560}-A_{720}\right)$. Melanoidin content was estimated based on the browning index (net absorbance $=A_{450}-A_{720}$ ) (Brudzynski \& Miotto, 20l la). Spectrophotometric measurements were performed in a $\mathrm{I} \mathrm{cm}$ quartz cell; results were expressed as absorbance units (AU).

\section{Sugar content}

The method used was in accordance with that reported by Anjos, Campos, Ruiz, and Antunes (2015).

\section{Total content of polyphenols}

The total polyphenol content was determined in honey solutions by the Folin-Ciocalteau method (Singleton \& Rossi, 1965). To test sugar interference, a sugar solution was made taking into account the sugar profile of each sample and two further dilutions were prepared for each one. The prepared sugar solutions were in accordance with the sugar content in the $50 \%$ honey solution prepared for pholyenols' estimation. Experiments were made in triplicates, and the results were expressed as mean \pm SD $\mathrm{mg}$ equivalent of gallic acid/ $100 \mathrm{~g}$ honey, after the elimination of sugar interference.

\section{Total flavonoid content}

The total flavonoid content (TFC) of different honey samples was determined using the aluminum chloride assay according to Samatha, Shyamsundarachary, Srinivas, and Swang (2012). To study a possible interference of sugars in this assay, the sugar solution made for polyphenol content estimation was also used. To avoid possible interaction of sample color with the reaction's reagents, the blank was constituted by water (substituting the other reaction's components) and the sample as reported by Sancho et al. (20|6), and the resulting absorbance was subtracted from the whole reaction absorbance before TFC estimation. The TFC was expressed in $\mathrm{mg}$ of chatechin equivalents (CE) per $100 \mathrm{~g}$ of honey as the mean of three triplicate \pm SD.

\section{Antioxidant activity}

All measurements described in this section were performed in triplicate, and the results were expressed as the mean $\pm S D$.

\section{Capacity for scavenging 2,2'-azino-bis(3- ethylbenzothiazoline-6-sulphonic acid)}

The determination of ABTS radical scavenging capacity was carried out as reported previously (Miguel, Nunes, Dandlen, Cavaco, \& Antunes, 20I0). Briefly, the ABTS radical was generated by the reaction of $A B T S$ aqueous solution $(7 \mathrm{mM})$ with Potassium persulfate $\left(\mathrm{K}_{2} \mathrm{~S}_{2} \mathrm{O}_{8}\right)$ $(2.45 \mathrm{mM})$ in the dark for $16 \mathrm{~h}$ and adjusting the absorbance at $734 \mathrm{~nm}$ to 0.7 at room temperature. The samples $(25 \mu \mathrm{l})$ were added to $275 \mu \mathrm{l}$ ABTS and the absorbance at $734 \mathrm{~nm}$ was read after $6 \mathrm{~min}$. Several concentrations of samples were used and the percentage inhibition calculated by applying the formula: $\left[\left(A_{0}-A_{1} /\right.\right.$ $\left.\left.A_{0}\right) \times 100\right]$, plotted against sample concentration, and $I_{50}$, or half maximal inhibitory concentration was determined. $A_{0}$ is the absorbance of the negative control (blank sample containing the same amount of water and ABTS solution); $A_{1}$ is the absorbance of the sample.

\section{Nitric oxide scavenging capacity}

The nitric oxide (NO) scavenging activity of samples was measured according to the method described by Ho, Tang, Lin, and Liew (2010). NO was generated from SNP and was measured by using the Griess reagent ( $N$-(I-Naphthyl) ethylenediamine). In this method, $50 \mu \mathrm{I}$ of serially diluted honey sample were added to $50 \mu \mathrm{l}$ of $10 \mathrm{mM}$ SNP $\left(\mathrm{Na}_{2}\left[\mathrm{Fe}(\mathrm{CN})_{5} \mathrm{NO}\right]\right)$ in phosphate buffer saline (PBS) into a 96-well plate, which was then incubated at room temperature for $90 \mathrm{~min}$. Finally, an equal volume of Griess reagent was added to each well and the absorbance was read at $546 \mathrm{~nm}$. Several concentrations of samples were made and the percentage inhibition calculated using the formula: $\left[I-\left(A_{\text {sample }}-A_{\text {sample blank }}\right) /\left(A_{\text {control }}-A_{\text {control blank }}\right)\right] \times$ 100 , where $\left(A_{\text {sample }}-A_{\text {sample blank }}\right)$ is the difference in the absorbance of a sample, with or without $10 \mathrm{mM}$ SNP, and $\left(A_{\text {control }}-A_{\text {control blank }}\right)$ is the difference in the absorbance of the PBS control, with or without $10 \mathrm{mM}$ SNP. The inhibition percentage was plotted against sample concentration and $\mathrm{IC}_{50}$ was determined (concentration of sample able to scavenge $50 \%$ of NO free radical).

\section{Chelating metal ions}

The degree of chelating of ferrous ions by honey samples was evaluated according to Miguel et al. (2010). Briefly, samples were incubated with $0.05 \mathrm{ml}$ of Iron(II) chloride, $\mathrm{FeCl}_{2} \cdot 4 \mathrm{H}_{2} \mathrm{O}(2 \mathrm{mM})$. The addition of $0.2 \mathrm{ml}$ of $5 \mathrm{mM}$ ferrozine initiated the reaction, and after $10 \mathrm{~min}$, the absorbance at $562 \mathrm{~nm}$ was measured. An untreated sample served as control. The percentage of chelating ability was determined according to the following formula: $\left[\left(A_{0}-A_{1}\right) / A_{0} \times 100\right]$, in which $A_{0}$ is the absorbance of the control and $A_{1}$ the absorbance of honey sample. The values of $\mathrm{IC}_{50}$ were determined as reported above for the previous assays.

\section{Superoxide anion radical $\left(\mathrm{O}_{2}^{-}\right)$scavenging activity (non-enzymatic method)}

Measurements of $\mathrm{O}_{2}^{-}$scavenging activity of honey samples were based on Soares (1996) method. $\mathrm{O}_{2}^{--}$were 
generated in a non-enzymatic phenazine methosulfatenicotinamide adenine dinucleotide (PMS-NADH) system based on the oxidation of NADH and assayed by reduction of nitroblue tetrazolium (NBT). The sample's IC $_{50}$ was then determined in triplicate for each sample.

\section{Statistical analysis}

One-way ANOVA was performed to determine significant differences among samples with a Scheffe post hoc test $(95 \%$ confidence level). The results were also subjected to a multivariate analysis (principal component analysis). All experimental data were analyzed using StatSoft Statistics (version 7).

\section{Results}

\section{Melissopalynological analysis}

The main question facing the analysis of pollen profile for monofloral honey determination is: at which level of a pollen species is necessary to reach for declaring the discriminating point between monofloral and multifloral honey. In all the analyzed samples of the present study, pollen grains of $B$. spinosum (Figure I(b)) were predominant (Table I), with percentages ranging from $48.8 \%$, in the sample S9, to $83.0 \%$, in the sample S5.

Regarding the previously mentioned limitations of melissopalynology, and the variability in the remaining pollens of each analyzed sample, the conclusion will not be final, and further detailed study will be needed. From the results of the present work it is possible to see that Thymus pollens could be detected in six samples, being the secondary pollen in two of them with percentages of $19.8 \%(\mathrm{~S} 2)$ and $21.3 \%(\mathrm{~S} 6)$, while Cardus spp. was secondary in S8 (25.3\%), S9 (24.5\%), SIO (22.2\%), and SII $(30.8 \%)$. For the remaining samples the secondary pollen was Olea spp. (S9), Cactus spp. (SI2), Opuntia spp. (SI and S3) (Table I). The occurrence of other pollens was also seen, namely: Acacia spp.; Epilobium spp.; Eragrostis spp.; Eucalyptus spp.; and Phoenix sp., although with percentages below 15\% (important minor pollen).

Pollen qualitative analysis provides important data for honey characterization, regarding the occurrence of nectariferous plants, harvest season, honey extraction and filtration, the occurrence of fermentations, as well the geographical origin (Von Der Ohe, Persano Oddo, Piana, Morlot, \& Martin, 2004). Keeping in mind the absence of any previous reference of this honey, the last indication is, in fact, one of the limitations of the present study to declare the "monoflorality" of this honey: honey production in different countries leads to the diffusion of different secondary plant nectars, and so changes the discriminatory percentage of the dominant pollen. This makes the 'ideal reference model' of monofloral type different from one analyst to another. This fact can be clearly seen in the variability of the same European monofloral honey, in terms of their pollen profile, from country to country (Persano Oddo et al., 2004).

More discussions about pollen profile will be addressed in the following sections of this work, as well as its possible influence on other honey parameters.

\section{Microbiological evaluation}

Microbial counts in organic honey samples are shown in Table 2. All honey samples had aerobic mesophilic bacteria, although the bacterial load was variable, with the highest level was recorded in sample S7. All samples were negative for Enterobacteriaceae and sulfite-reducing Clostridium spp. The counts of aerobic mesophilic bacteria in the samples S6, S7 and SI2 suggest that the hygiene conditions of the honey production must be improved. The low numbers of aerobic mesophilic bacteria in the majority of the honey samples and the absence of Enterobacteriaceae and sulfite-reducing Clostridium spp. do, however, indicate the safe consumption of this honey.

\section{Physico-chemical analyzes}

Tables 2 and 3 present the results of the physico-chemical parameters analyzed in the twelve samples of honey. From a quality point of view, the analyzed samples were, in most cases, within European limits (EU Council, 2002) or the Codex Alimentarius (200I), and showed no alarming values. However a significant variability was observed.

In all the analyzed samples, $\mathrm{pH}$ values, with 3.82 \pm 0.16 as a mean didn't show any outset value, to be in accordance with Malika, Mohamed, and Chakib (2005) and Bettar et al. (in press), who analyzed Moroccan honeys from different floral origin. The same observation made for lactonic acidity, free acidity, and the total acidity, for which the mean values were, respectively, $16.58 \pm 1.40,25.70 \pm 6.46$ and $42.28 \pm 6.76 \mathrm{meq} / \mathrm{kg}$. It has to be mentioned that (EU Council, 2002) fixed honey free acidity to values bellow $50 \mathrm{mEq} / \mathrm{kg}$, which is important for avoiding undesirable fermentations.

Another determinant parameter in a possible fermentation process (Mendes, Proença, Ferreira, \& Ferreira, 1998) is the moisture percentage, that ranged from $17.3 \%$ (S7) to $20.5 \%$ (SII) (Table 3), exceeding so $20 \%$, or the maximum allowed by (Codex Alimentarius, 200I), and the EC directive (EU Council, 2002). Furthermore sample S4, S5 were also above the required limit.

According to the European Unit EU Council (2002), the values of electrical conductivity and ash must not exceed $800 \mu \mathrm{S} / \mathrm{cm}$ and $0.6 \%$, respectively. Amongst the studied samples (Table 2 ), only $\mathrm{SI} 2$ had an electrical conductivity higher than the maximum recommended value, which was coincident with the highest percentage of ash $(0.37 \%)$. Indeed, the electrical conductivity depends on the ash and acid content, which, per se, 


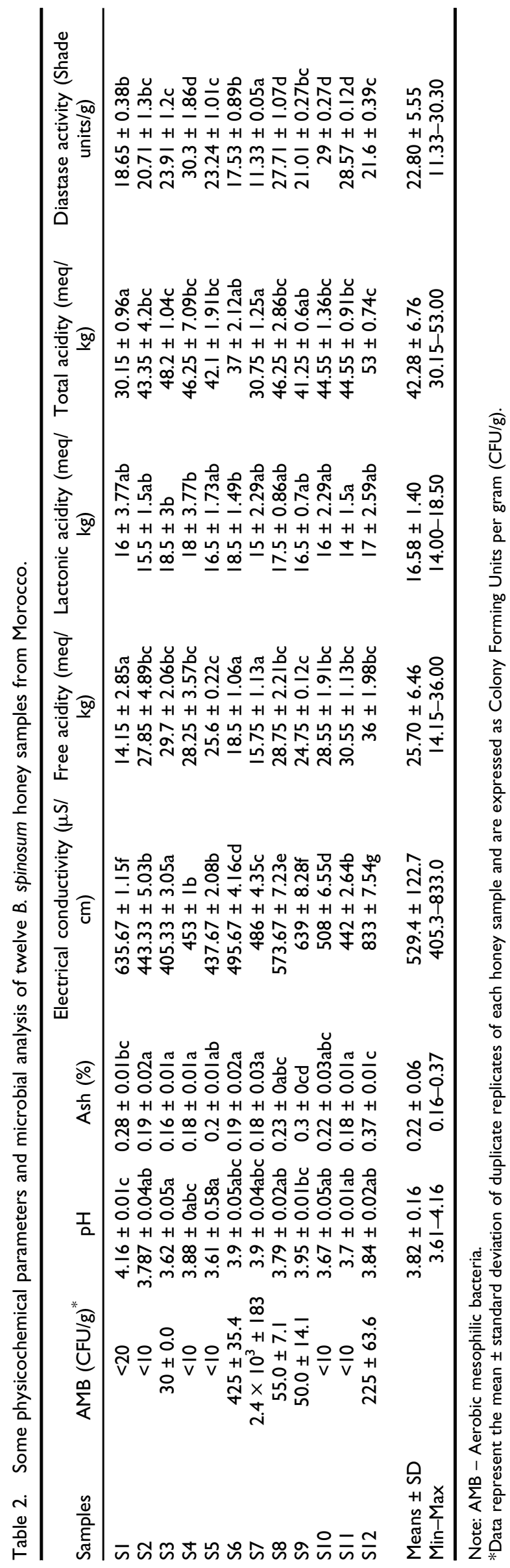




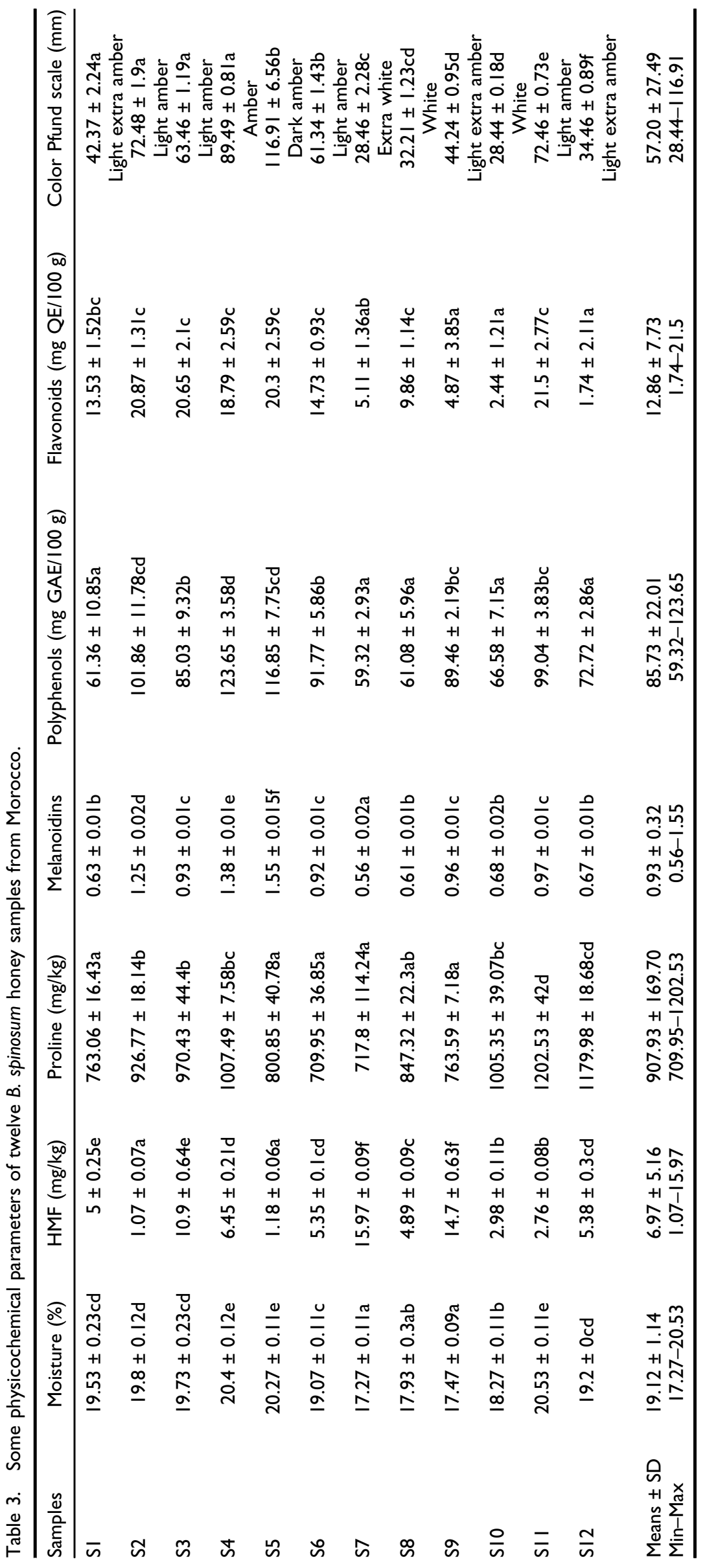


reflects the presence of ions and organic acids; the higher their content, the higher the resulting conductivity (Feás, Pires, Estevinho, Iglesias, \& De Araujo, 2010).

It is well known that honey diastase activity is one of the indicators telling about storage conditions and/or processing, and it is used for honey freshness confirmation in routine analysis because of its sensitivity to heat or inadequate storage condition, (Anklam, 1998). Nevertheless, its level also depends on the geographic and floral origins of samples (Fallico, Arena, Verzera, \& Zappalà, 2006). All honey samples studied in the present work had higher diastase activity than the minimum required ( 8.0 Shade units/g) by European legislation (EU Council, 2002). Nevertheless it is noteworthy to refer that a great variability was found among samples (II.3 in S7 to 30.3 Shade units/g in S4) (Table 2).

Hydroxymethylfurfural (HMF) is one of the most known Amadori compounds, formed during the thermal treatments of carbohydrate-containing foods as a result of Maillard reaction, becoming another honey freshness indicator. This compound is found only in trace amount in fresh honey, with values bellow $40 \mathrm{mg} / \mathrm{kg}$, the maximal value allowed by Codex Alimentarius (200I) and EU Council (2002). Based on this parameter, all the analyzed samples showed freshness signs, with values ranging from $1.1 \mathrm{mg} / \mathrm{kg}$ in S2 to $16.0 \mathrm{mg} / \mathrm{kg}$ in $\mathrm{S} 7$, collected in 2013 and 2011 , respectively (Table 3 ).

In the present work, proline evaluation was followed according to the IHC method, although other methods can be used, as previously reported by Truzzi, Annibaldi, Illuminati, Finale, and Scarponi (20l4). All honey samples contained more than the minimum acceptable proline concentration, i.e., $200 \mathrm{mg} / \mathrm{kg}$ (Hermosín, Chicón, \& Cabezudo, 2003), nevertheless its amounts varied greatly among samples $(710.0 \mathrm{mg} / \mathrm{kg}$ in $\mathrm{S} 6$ and $1202.5 \mathrm{mg} / \mathrm{kg}$ in SI I) (Table 3).

Honey color is an indicator of the presence of compounds, such as polyphenols, terpenes and carotenoids (Naab et al., 2008). In the analyzed honey samples a great variability of color, determined at $A_{635}$, was observed: from extra white ( $28.5 \mathrm{~mm}$ Pfund) in S7 sample to dark amber (I $16.9 \mathrm{~mm}$ Pfund) in S5 (Table 3). A strong correlation was observed between color and melanoidin content $(r=0.948 ; p<0.01)$ (Figure I), confirming their participation in the resulting honey color (Brudzynski \& Maldonado-Alvarez, 20I5), and explaining the variability seen amongst the analyzed samples (Table 3). Melanoidins, or Maillard reaction products, estimated as a difference between two wavelengths $\left(A_{560}-A_{720}\right)$, are multi-component polymers consisting of proteinpolyphenol-oligosaccharide complexes, which along with phenols are responsible for the antioxidant activity of honey (Brudzynski \& Miotto, 20II; Moussa, Saad, \& Noureddine, 2012).

As the Folin-Ciocalteau reagents can not only oxidize phenolic molecules, but also non-phenolic organic compounds, (Pękal \& Pyrzynska, 20l4), such as reducing sugars, sugar effect was studied. For this, the assay reaction was applied on sugar solutions for each sample based on its sugar profiling, and the values were subtracted from total polyphenol estimation, to obtain the results illustrated in Table 3. The effect of dilution on sugar interference was also evaluated, being the assay initiated with solutions with sugar content equivalent to that of $50 \%$ honey solution, and $12.5 \%$. This concentration was also that used for the estimation of polyphenols in honey samples. The results showed a clear interference of sugars when they were in concentration of $50 \%$, with values between $16.83 \pm 0.67$, for $\mathrm{SIO}$, and $23.67 \pm 2.35 \mathrm{mg} \mathrm{GA}$ equivalent/100 g honey, for SI. In fact, polyphenol estimation was not possible in $50 \%$ honey solution, and a 1/4 dilution was used, so the same was done on sugar solutions. A clear decrease in sugar interference was observed with dilution and the values passed from $19.26 \pm 2.43 \mathrm{mg}$ GAE/l00 $\mathrm{g}$ as the mean of all sugar solutions $50 \%$ to $7.28 \pm 3.13 \mathrm{mg} \mathrm{GAE} /$ $100 \mathrm{~g}$ in the $1 / 4$ dilution.

Without sugar effect elimination, polyphenol content ranged from $66.15 \mathrm{mg}$ GAE/l00 g (SI) to a maxi-

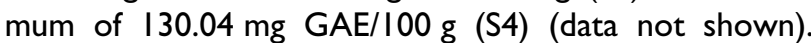
These values were significantly lower than that reported for other Moroccan honey types (Aazza, Lyoussi, Antunes, \& Miguel, 2014). In addition and taking into account the sugar interference, the respective values were even lower because they ranged from $61.36 \pm 10.85 \mathrm{mg}$ GAE/I00 g (SI) to $123.65 \pm 3.58 \mathrm{mg}$ $\mathrm{GAE} / 100 \mathrm{~g}$ (S4).

Several methods are used for the quantification of total flavonoids, in spite of the interferences of some reagents with some flavonoid classes, being therefore a limitation of the method in unknown samples analysis (Mammen \& Daniel, 20I2; Pękal \& Pyrzynska, 20l4). The same authors proved that rutin, luteolin and catechins seem to be more accurate with the sodium nitrite $\left(\mathrm{NaNO}_{2}\right)$ used in some methods for flavonoid determination. For this reason, in the present work catechin was used as standard. As expected from the polyphenol content results, flavonoid content was also reduced compared to other Moroccan honeys, and the values ranged from I.74 to $20.87 \mathrm{mg} \mathrm{CE} / \mathrm{l} 00 \mathrm{~g}$ of honey. The effect of sugar on flavonoid estimation in honey samples was also studied and no interference was detected, independent of the dilution (data not shown).

Positive correlations were obtained between color, melanoidin, phenol and flavonoid contents (Figure 2). These results reveal that polyphenols and melanoidins play a role in honey color. Correlations between phenols, melanoidins and flavonoids may be attributed to the fact that all these compounds absorb light in the visible range, as previously reported by Aazza et al. (20l4) for Moroccan honeys of diverse floral origin. The samples S2, S4, S5 and SII from Ait Bazza, Ait Bouilloul and Bouiblane respectively, presented the highest values of phenols, melanoidins and flavonoids (Figure 2). Additionally the color and the electrical conductivity give an indication of the botanical origin of honey. 


\section{Sugar content}

Fructose and glucose are the major monosaccharides in honey, and their proportion depends on nectar delivering plant (Anklam, 1998). Their sum in the analyzed honey samples ranged from $56.9 \%$ in SI to $69.9 \%$ in S8, (Table 4) which were in accordance with those reported by other authors that analyzed honey from different origin (Anjos, Campos et al., 2015; Shin \& Ustunol, 2005). The concentration of fructose ranged from $34.4 \mathrm{~g} / 100 \mathrm{~g}$ in SI sample to $42.3 \mathrm{~g} / 100 \mathrm{~g}$ in S3 and could be found 5 homogenous groups with statistic differences from the 12 analyzed samples (Table 4). Sample SI had also the lowest concentration of glucose $(22.2 \mathrm{~g} / \mathrm{l} 00 \mathrm{~g})$, while $\mathrm{S} 8$ had the highest amount of this monosaccharide $(31.0 \mathrm{~g} / \mathrm{l} 00 \mathrm{~g})$.

Practically all samples had sucrose lower that the quantification limit $(<0.2 \mathrm{~g} / 100)$ except $\mathrm{SI} 2$ that presented $4.3 \mathrm{~g} / 100 \mathrm{~g}$ of sucrose, but still lower than the limit of $5 \%$ allowed by the Codex Alimentarius (200I) for this sugar. Its structural isomer, turanose, as well as maltose were not detected also, except for sample S4 which had $1.8 \mathrm{~g} / \mathrm{l} 00 \mathrm{~g}$ of maltose.

Trehalose was the most important disaccharide present in the zandaz honey samples, for which the occurrence with such relative high levels is, generally, not usual in honeys (Anjos, Campos et al., 2015) and could be a discriminant characteristic of zandaz honey.

Another relevant characteristic in this honey type was the occurrence of melezitose, which is absent in unifloral honeys with the exceptions of heather, chestnut and cardoon (Aazza, Lyoussi, Antunes, \& Miguel, 2013; Mateo \& Bosch-Reig, 1997), but is very common, even with higher levels, in honeydew (Bogdanov, Ruoff, \& Persano-Oddo, 2004). In the present work, and independent of the region where the samples were collected, high levels of this trisaccharide were detected (1.5-2.8 g/l00 g).

From a discriminatory point of view, and as expected from pollen spectrum, even with a predominance of $B$. spinosum pollen, the results of physico-chemical characterization showed variability. This makes the task to declare the monoflorality or not of the so called zandaz honey more complicated.

It is well established that the above studied parameters, when recorded at extreme low or high values, can be used as a discriminatory pattern to support the melissopalynological results. Low values of G/W ratio and high values of color, electric conductivity, enzymes, $\mathrm{pH}$ and $\mathrm{F} /$ $\mathrm{G}$ ratio, when associated with more than $90 \%$ of chestnut pollen, constitute a discriminatory characterization for this monofloral honey (Persano Oddo et al., 2004). In contrast, and in the same reference, the physico-chemical pattern of lavender unifloral honey is characterized by low values of electrical conductivity, slightly low $F+G$ and high values of sucrose. Focusing on the means of some analyzed parameters, lead to the easy misclassification of the samples with other honey types. The electrical conductivity and color are similar to those of dandelion, and eucalyptus honeys (Persano Oddo et al., 2004).

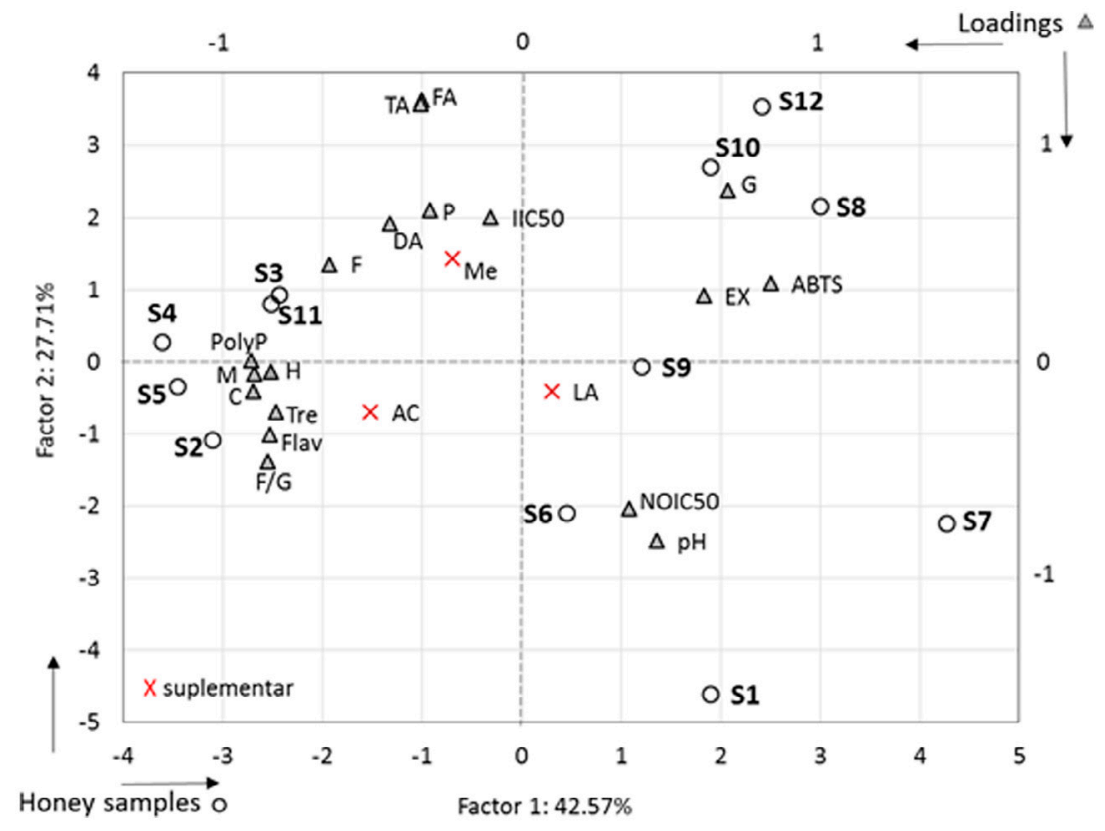

Figure 2. Principal component analysis with all measured parameter: projection of loadings and honey samples in the same system of vectors. Legend: FA - free acidity (mEq/kg); LA - lactonic acidity $(\mathrm{mEq} / \mathrm{kg})$; TA - total acidity (mEq/kg); EX - electrical conductivity $\mathrm{mS} / \mathrm{cm}$; AC - ash content \%; $\mathrm{H}$ - water content \%; C - color (Pfund); $\mathrm{M}$ - melanoidines; DA - diastase activity (shade number); P - proline mg/kg; PolyP - phenol (mg GAE/l00 g); Flav - flavonoids mg QE/I00 g; ABTS - ABTS IC 50 (mg/ml); IIC50 - iron chelating power $\mathrm{IC}_{50}(\mathrm{mg} / \mathrm{ml})$; NOIC50 - nitric oxide $\mathrm{IC}_{50}(\mathrm{mg} / \mathrm{mL}) ; \mathrm{F}$ - fructose $(\mathrm{g} / \mathrm{IO0} \mathrm{g}) ; \mathrm{G}$ - glucose $(\mathrm{g} / \mathrm{l} 00 \mathrm{~g})$; Me - melezitose $(\mathrm{g} /$ $100 \mathrm{~g})$; Tre - trehalose (g/l00 g); F/G - fructose/glucose ratio. 
Table 4. Sugar content $(\mathrm{g} / \mathrm{l} 00 \mathrm{~g})$ of twelve B. spinosum honey samples from Morocco.

\begin{tabular}{|c|c|c|c|c|c|c|c|c|c|}
\hline Samples & Fructose & Glucose & Sucrose & Maltose & Melezitose & Trehalose & Turanose & $\begin{array}{c}\text { Fructose+ } \\
\text { glucose }\end{array}$ & $\begin{array}{l}\text { Fructose/ } \\
\text { glucose }\end{array}$ \\
\hline SI & $34.7 \pm 1.8 a$ & $22.2 \pm 1.0 \mathrm{a}$ & $<0.2$ & $<0.2$ & $2.8 \pm 0.1 b$ & $2.1 \pm 0.1 \mathrm{ab}$ & $<0.2$ & $56.9 \pm 2.8 c d$ & $\mathrm{I} .56 \pm 0.0 \mathrm{la}$ \\
\hline S2 & $40.0 \pm 0.6 d$ & $23.4 \pm 0.4 b$ & $<0.2$ & $<0.2$ & $\mathrm{I} .7 \pm 0.1 \mathrm{a}$ & $4.7 \pm 0.1 b$ & $<0.2$ & $63.4 \pm 1.0 \mathrm{de}$ & $\mathrm{I} .7 \mathrm{I} \pm 0.00 \mathrm{ab}$ \\
\hline S3 & $42.3 \pm 0.2 \mathrm{e}$ & $24.4 \pm 0.1 b$ & $<0.2$ & $<0.2$ & $\mathrm{I} .5 \pm 0.1 \mathrm{a}$ & $4.1 \pm 0.1 \mathrm{ab}$ & $<0.2$ & $66.7 \pm 0.4 \mathrm{e}$ & $1.73 \pm 0.00 b$ \\
\hline S4 & $39.8 \pm 0.4 d$ & $24.6 \pm 0.2 b$ & $<0.2$ & $\begin{array}{l}1.8 \\
\pm 0.1\end{array}$ & $2.2 \pm 0.3 \mathrm{ab}$ & $4.0 \pm 0.1 \mathrm{ab}$ & $<0.2$ & $64.4 \pm 0.6 \mathrm{~cd}$ & $\mathrm{I} .62 \pm 0.0 \mathrm{Iab}$ \\
\hline S5 & $38.7 \pm 0.0 c d$ & | $24.2 \pm 0.0 b$ & $<0.2$ & $<0.2$ & $2.0 \pm 0.1 \mathrm{ab}$ & $2.2 \pm 1.7 a b$ & $<0.2$ & $62.9 \pm 0.1 \mathrm{~cd}$ & $1.60 \pm 0.00 \mathrm{ab}$ \\
\hline S6 & $38.1 \pm 0.3 c d$ & $26.8 \pm 0.3 d$ & $<0.2$ & $<0.2$ & $1.7 \pm 0.0 \mathrm{a}$ & $3.1 \pm 0.0 \mathrm{ab}$ & $<0.2$ & $64.9 \pm 0.5 b$ & $\mathrm{I} .42 \pm 0.00 \mathrm{~b}$ \\
\hline S7 & $36.5 \pm 0.8 b$ & $28.5 \pm 0.2 d$ & $<0.2$ & $<0.2$ & $2.0 \pm 0.1 \mathrm{ab}$ & $1.6 \pm 0.0 \mathrm{a}$ & $<0.2$ & $65.0 \pm 1.0 \mathrm{a}$ & $1.28 \pm 0.02 b$ \\
\hline S8 & $38.9 \pm 0.6 c d$ & $131.0 \pm 0.3 \mathrm{e}$ & $<0.2$ & $<0.2$ & $\mathrm{I} .8 \pm 0.2 \mathrm{a}$ & $1.3 \pm 0.0 \mathrm{a}$ & $<0.2$ & $69.9 \pm 1.0 \mathrm{a}$ & $\mathrm{I} .25 \pm 0.0 \mathrm{lb}$ \\
\hline 59 & $39.1 \pm 0.5 \mathrm{~cd}$ & $27.0 \pm 0.2 d$ & $<0.2$ & $<0.2$ & $2.0 \pm 0.1 \mathrm{ab}$ & $2.1 \pm 0.0 \mathrm{ab}$ & $<0.2$ & $66.1 \pm 0.4 b$ & $\mathrm{I} .45 \pm 0.0 \mathrm{lb}$ \\
\hline SIO & $36.5 \pm 0.2 b$ & $28.7 \pm 0.0 \mathrm{~d}$ & $<0.2$ & $<0.2$ & $1.9 \pm 0.1 \mathrm{a}$ & $2.0 \pm 0.0 \mathrm{ab}$ & $<0.2$ & $65.2 \pm 0.2 a$ & $\mathrm{I} .27 \pm 0.0 \mathrm{lb}$ \\
\hline SII & $38.4 \pm 1.8 \mathrm{~cd}$ & $25.4 \pm \mathrm{I} . \mathrm{IC}$ & $<0.2$ & $<0.2$ & $1.9 \pm 0.0 \mathrm{a}$ & $4.0 \pm 0.26 \mathrm{ab}$ & $<0.2$ & $63.8 \pm 2.8 b c$ & $\mathrm{I} .5 \mathrm{I} \pm 0.0 \mathrm{lab}$ \\
\hline $\mathrm{SI} 2$ & $37.6 \pm 1.9 b c$ & $28.9 \pm 0.3 d$ & $4.3 \pm 0.2$ & $<0.2$ & $2.0 \pm 0.2 a$ & $\mathrm{I} . \mathrm{I} \pm 0.0 \mathrm{a}$ & $<0.2$ & $66.5 \pm 2.1 \mathrm{a}$ & $\mathrm{I} .30 \pm 0.05 \mathrm{~b}$ \\
\hline Mean \pm SD & $38.4 \pm 2.0$ & $26.3 \pm 2.7$ & & & $2.0 \pm 0.3$ & $2.7 \pm 1.2$ & & $64.6 \pm 3.1$ & $1.48 \pm 0.17$ \\
\hline Min-max & $34.7-42.3$ & $22.2-31.0$ & & & I.5-2.8 & I.I-4.7 & & $56.9-69.9$ & $1.25-1.74$ \\
\hline
\end{tabular}

\section{Antioxidant activity}

The antioxidant activities of the honey samples were measured using four different methods: three assays assessed the capacity for scavenging free radicals (ABTS, superoxide, and NO) and one assay to assess samples' capacity for chelating metal ions. The results are shown in Table 5. Sample S2 was the best for scavenging ABTS free radicals. The sample $S 4$ was also a good scavenger of ABTS free radicals, along with S5. Samples SI, S2 and S6 were those honey samples that presented the best capacity for scavenging the superoxide anion radicals, whereas S9, SIO and SI2 where those which had the best capacity for scavenging $\mathrm{NO}$ radicals. The capacity for chelating metal ions was higher in samples SI, S2 and S6 (Table 5).

The capacity for scavenging ABTS free radicals by samples, measuring the absorbance at $734 \mathrm{~nm}$, changes proportionally with incubation time, nevertheless Sancho et al. (2016) observed that there were no differences between activity measuring the absorbance at $60 \mathrm{~min}$ and calculated activity at $60 \mathrm{~min}$, by measuring absorbance at $6 \mathrm{~min}$, independent on the type of honey and extract. The activity in the present work was followed by measuring the absorbance after 6 min of reaction.

The antioxidant activity of honey samples depends on the honey floral origin, because of the differences in the content of plant secondary metabolites such as polyphenolics, and enzyme activities (Alvarez-Suarez, Giampieri, \& Battino, 2013; Sousa et al., 2016). However, the same monofloral honey may present diverse antioxidant activities as found in the present work, since the polyphenol content may vary. Such findings were already reported by Aazza et al. (20l4) for the same monofloral honeys (thyme and jujube) from Morocco of different geographic origins. The results of the present work also show that the capacity for scavenging free radicals depends on the type of radicals used, whereby it is important to discriminate the type of radicals that honey samples are able to scavenge.

Flavonoid content correlated positively with the honey color, melanoidins and phenol content but negatively with the $I_{50}$ values of the scavenging capacity of ABTS free radicals (Figure 2). Proline amount positively correlated with the $\mathrm{IC}_{50}$ values of the capacity for chelating metal ions and scavenging superoxide free radicals. The negative correlation between HMF content and antioxidant activity (e.g., $I_{50}$ values for ABTS assay) was not as evident as observed for phenols and antioxidant activity. The weak correlation between those two factors was already reported (Gheldof, Wang, \& Engeseth, 2002) for honey samples, being the breakdown products of HMF the most probable contributors for the antioxidant activity of honey samples.

The negative correlation between $\mathrm{IC}_{50}$ values of $\mathrm{NO}$ scavenging activity and proline content may reveal an important role of this amino acid on the capacity for scavenging that free radical. Antioxidant activity of some amino acids (histidine, taurine, glycine, alanine, proline) has been reported (Meda, Lamien, Romito, Millogo, \& Nacoulma, 2005; Wu, Shiau, Chen, \& Chiou, 2003). Such property of proline may indicate some anti-inflammatory activity of these honeys since NO appears at higher concentrations during inflammatory reactions. Compounds with the capacity for scavenging $\mathrm{NO}$ can be therefore considered as possessing antioxidant and antiinflammatory properties. Color was strongly correlated with the capacity of samples to scavenge ABTS free radicals (Figure 2). The same happened with the capacity for scavenging these free radicals and melanoidins as reported before. The correlation of color and antioxidant activity as well as between melanoidin and 
Table 5. Antioxidant activity and capacity for scavenging free radicals of twelve B. spinosum honey samples from Morocco.

\begin{tabular}{lcccc}
\hline Samples & $\mathrm{ABTS} \mathrm{IC}_{50}(\mathrm{mg} / \mathrm{ml})$ & Superoxide $I C_{50}(\mathrm{mg} / \mathrm{ml})$ & Nitric oxide $I C_{50}(\mathrm{mg} / \mathrm{ml})$ & Iron chelating power IC $50(\mathrm{mg} / \mathrm{ml})$ \\
\hline SI & $7.06 \pm 0.26 \mathrm{~b}$ & $9.92 \pm 0.05 \mathrm{a}$ & $167.03 \pm 16.78 \mathrm{c}$ & $9.92 \pm 0.05 \mathrm{a}$ \\
S2 & $4.94 \pm 0.13 \mathrm{a}$ & $7.97 \pm 0.1 \mathrm{a}$ & $121.25 \pm 0.7 \mathrm{lab}$ & $7.97 \pm 0.1 \mathrm{a}$ \\
S3 & $7.40 \pm 0.09 \mathrm{~b}$ & $86.8 \pm 1.68 \mathrm{c}$ & $135.39 \pm 1.86 \mathrm{~b}$ & $86.80 \pm 1.68 \mathrm{c}$ \\
S4 & $4.62 \pm 0.08 \mathrm{a}$ & $75.45 \pm 6.23 \mathrm{c}$ & $95.54 \pm 0.99 \mathrm{ab}$ & $75.45 \pm 6.23 \mathrm{c}$ \\
S5 & $4.20 \pm 0.03 \mathrm{a}$ & $132.19 \pm 2.94 \mathrm{~d}$ & $93.82 \pm 15.67 \mathrm{ab}$ & $132.19 \pm 2.94 \mathrm{~d}$ \\
S6 & $6.44 \pm 0.15 \mathrm{~b}$ & $10.06 \pm 0.26 \mathrm{a}$ & $143.11 \pm 0.34 \mathrm{bc}$ & $10.06 \pm 0.26 \mathrm{a}$ \\
S7 & $10.06 \pm 0.86 \mathrm{c}$ & $51.64 \pm 2.75 \mathrm{bc}$ & $189.60 \pm 0.43 \mathrm{c}$ & $51.64 \pm 2.75 \mathrm{bc}$ \\
S8 & $12.18 \pm 0.2 \mathrm{~d}$ & $49.74 \pm 3.24 \mathrm{bc}$ & $137.42 \pm 5.22 \mathrm{bc}$ & $49.74 \pm 3.24 \mathrm{bc}$ \\
S9 & $6.50 \pm 0.16 \mathrm{~b}$ & $31.88 \pm 0.47 \mathrm{ab}$ & $81.98 \pm 3.44 \mathrm{a}$ & $31.88 \pm 0.47 \mathrm{ab}$ \\
SI0 & $9.03 \pm 0.3 \mathrm{c}$ & $173.20 \pm 33.84 \mathrm{e}$ & $75.75 \pm 1.9 \mathrm{a}$ & $173.20 \pm 33.84 \mathrm{e}$ \\
SII & $6.36 \pm 0.16 \mathrm{~b}$ & $80.94 \pm 2 \mathrm{c}$ & $110.12 \pm 2.86 \mathrm{ab}$ & $80.94 \pm 2 \mathrm{c}$ \\
SI2 & $9.56 \pm 0.25 \mathrm{c}$ & $101.97 \pm 3.61 \mathrm{ld}$ & $69.60 \pm 3.06 \mathrm{a}$ & $101.97 \pm 3.61 \mathrm{~d}$ \\
Means \pm SD & $7.37 \pm 2.42$ & $51.31 \pm 25.65$ & $118.38 \pm 37.45$ & $67.65 \pm 51.48$ \\
Min-Max & $4.20-12.18$ & $15.02-81.96$ & $69.60-189.60$ & $7.98-173.21$
\end{tabular}

antioxidant activity were also previously reported by Aazza et al. (20/4), in Moroccan honeys of different floral origins.

\section{Variance explained by principal component analysis}

A principal component analysis was performed with all analytical data of $B$. spinosum honey from the 12 sites (Figure 2) to establish the differences among samples. For the PCA, two replicates of the physicochemical parameters were used (minimum and maximum) since for the sugar content, only two duplicate values of each analysis were available. Three samples (variables) were projected as supplementary variable because they do not contribute significantly to variance explanation (ash content, lactonic Acidity, and melizetose) in the first two components.

Factor I could be identified as the phenol content component, includes a series of properties, which are significantly correlated amongst themselves: phenols content; melanoidins; flavonoids; color; F/G ratio as well trehalose, fructose and water content. ABTS $I_{50}$ and glucose content are also correlated with the previously mentioned group of properties, but negatively. The second component could be identified as the component related to the honey acidity. This factor correlated well iron chelating power $\mathrm{IC}_{50}$, superoxide $\mathrm{IC}_{50}$ and nitric oxide $\mathrm{IC}_{50}$ with $\mathrm{pH}$, diastase activity, proline, free acidity and total acidity.

The principal component analyzes explain $70.3 \%$ of the total variance observed (Figure 2). Moreover some samples are very similar, namely SI0, SI2, S8 and other group composed by the samples S2, S3, S4, S5, SII, the separation are not so large reason by which it was not possible to group the samples belonging to different geographical regions (Figure 2). The separation between the previously groups are given basically by the sugar content and total flavonoids and polyphenol content, that could be explained by the different composition in the secondary floral resources. Given this result it is possible conclude that the zandaz honey from the different regions under study possesses similar properties.

\section{Discussion}

While this is the first study reporting a preliminary investigation of some features of zandaz honey, characterized by the domination of $B$. spinosum pollen, and regarding the variability that can occur in the same type of honey, it was not easy to claim determinant conclusions. In all analyzed samples pollen count of $B$. spinosum exceeded $45 \%$, suggesting the monofloraty of this honey. Other relevant feature that can be used for zandaz honey characterization is the occurrence of trehalose and melizetose, which is unusual in almost honey types.

The use of PCA allowed also seeing homogeneity in the analyzed samples, a reason that did not allow grouping them into geographical groups, suggesting that belonging, or not, to a given region, zandaz honey conserved similar properties. To support the conclusions of the present study about this honey, large size samples will be needed, and subjected to the same analyzed parameters, with others evolving, mainly, sensory investigation and composition profiling.

\section{Acknowledgments}

The authors are grateful to Fundacão para a Ciência e Tecnologia for Research Center Grant UID/BIM/04773/2013 CBMR 1334; UID/AGR/00239/20I3; UID/BIA/04050/20I3 (POCl-0I-0I45-FEDER-007569); and to ERDF through the COMPETE2020 - Programa Operacional Competitividade e Internacionalização (POCl).

\section{Disclosure statement}

No potential conflict of interest was reported by the authors. 


\section{ORCID}

Youssef Elamine (1) http://orcid.org/0000-0002-8650-I580

Ofélia Anjos (i) http://orcid.org/0000-0003-0267-3252

Maria Leonor Faleiro (D) http://orcid.org/0000-0002-3878-6948

Maria Graça Miguel (D) http://orcid.org/0000-0003-2507-4228

\section{References}

Aazza, S., Lyoussi, B., Antunes, D., \& Miguel, M.G. (20I3). Physico-chemical characterization and antioxidant activity of commercial Portuguese honeys. Journal of Food Science, 78, CII59-CII65.

Aazza, S., Lyoussi, B., Antunes, D., \& Miguel, M.G. (2014). Physicochemical characterization and antioxidant activity of 17 commercial Moroccan honeys. International Journal of Food Sciences and Nutrition, 65, 449-457.

Alvarez-Suarez, J.M., Giampieri, F., \& Battino, M. (20/3). Honey as a source of dietary antioxidants: Structures, bioavailability and evidence of protective effects against human chronic diseases. Current Medicinal Chemistry, 20, 621-638

Anjos, O., Campos, M.G., Ruiz, P.C., \& Antunes, P. (2015). Application of FTIR-ATR spectroscopy to the quantification of sugar in honey. Food Chemistry, 169, 218-223.

Anklam, E. (1998). A review of the analytical methods to determine the geographical and botanical origin of honey. Food Chemistry, 63, 549-562. doi:10.1016/S0308-8146(98) 00057-0

Bettar, I.M., González-Miret, L., Hernanz, D., Marconi, A., Heredia, F.J., \& Terrab, A. (in press). Characterization of Moroccan spurge (Euphorbia) honeys by their physicochemical characteristics, mineral contents and color. Arabian Journal of Chemistry. Retrieved January 9, 2015 from http://www.sciencedirect.com/science/article/pii/SI 87 8535215000155

Bogdanov, S. (2002). Harmonized methods of the International Honey Commission. Retrieved from http://www.apicultura cluj.com/ApiculturaCluj/italiano/Documents/lHCmethods_e. pdf

Bogdanov, S., Ruoff, K., \& Persano-Oddo, L. (2004). Physicochemical methods for the characterization of unifloral honeys: A review. Apidologie, 35, S4-SI7.

Bouseta, A., Scheirman, V., \& Collin, S. (1996). Flavor and free amino acid composition of lavender and eucalyptus honeys. Journal of Food Science, 61, 683-687. doi:10.1111/j.13652621.1996.tb|2181.x

Brudzynski, K., \& Maldonado-Alvarez, L. (2015). Polyphenolprotein complexes and their consequences for the redox activity, structure and function of honey. A current view and new hypothesis - A review. Polish Journal of Food and Nutrition Sciences, 65, 7I-80.

Brudzynski, K., \& Miotto, D. (20II). The recognition of high molecular weight melanoidins as the main components responsible for radical-scavenging capacity of unheated and heat-treated Canadian honeys. Food Chemistry, 125, 570-575.

Codex Alimentarius, C. (200I). Revised codex standard for honey. Codex STAN, I2, 1981.

de la Fuente, E., Ruiz-Matute, A.I., Valencia-Barrera, R.M., Sanz, J., \& Martínez Castro, I. (20II). Carbohydrate composition of Spanish unifloral honeys. Food Chemistry, 129, I4831489. doi: 10.1016/j.foodchem.201 I.05.121

Escriche, I., Kadar, M., Juan-Borrás, M., \& Domenech, E. (2014). Suitability of antioxidant capacity, flavonoids and phenolic acids for floral authentication of honey. Impact of industrial thermal treatment. Food Chemistry, 142, I35-143. doi:I0.1016/j.foodchem.2013.07.033
EU Council. (2002). Council directive 200I/II O/EC of 20 December 2001 relating to honey. Official Journal of European Communities, LIO, 47-52.

Fallico, B., Arena, E., Verzera, A., \& Zappalà, M. (2006). The European Food Legislation and its impact on honey sector. Accreditation and Quality Assurance, II, 49-54.

Feás, X., Pires, J., Estevinho, M.L., Iglesias, A., \& De Araujo, J.P.P. (20I0). Palynological and physicochemical data characterization of honeys produced in the Entre-Douro e Minho region of Portugal. International Journal of Food Science and Technology, 45, I255-1262.

Gheldof, N., Wang, X.H., \& Engeseth, N.J. (2002). Identification and quantification of antioxidant components of honeys from various floral sources. Journal of Agricultural and Food Chemistry, 50, 5870-5877.

Gomes, S., Dias, L.G., Moreira, L.L., Rodrigues, P., \& Estevinho, L. (2010). Physicochemical, microbiological and antimicrobial properties of commercial honeys from Portugal. Food and Chemical Toxicology, 48, 544-548.

Hermosín, I., Chicón, R.M., \& Cabezudo, M.D. (2003). Free amino acid composition and botanical origin of honey. Food Chemistry, 83, 263-268.

Ho, S.C., Tang, Y.L., Lin, S.M., \& Liew, Y.F. (2010). Evaluation of peroxynitrite scavenging capacities of several commonly used fresh spices. Food Chemistry, 119, II02-1107.

ISO 15213:2003. (2003). Microbiology of food and animal feeding stuffs - Horizontal method for the enumeration of sulfite-reducing bacteria growing under anaerobic conditions. Switzerland: International Standards Organization.

ISO 2I528-2:2004 (E). (2004). Microbiology of food and animal feeding stuffs - Horizontal method for the detection and enumeration of Enterobacteriaceae - Part 2: Colony-count method. Retrieved from http://www.iso.org/iso/home/s tore/catalogue_tc/catalogue_detail.htm? csnumber $=34566$

Khabbch, A., Libiad, M., \& Ennabili, A. (2014, enero-junio). Luna Azul, 38, |7I-190. ISSN 1909-2474. doi:10.17|5|/ luaz.2015.40.2

Louveaux, J., Maurizio, A., \& Vorwohl, G. (1978). Methods of melissopalynology. Bee World, 59, 139-157. doi:10.1080/ 0005772X.1978.110977|4

Malika, N., Mohamed, F., \& Chakib, E.A. (2005). Microbiological and physico-chemical properties of Moroccan honey. International Journal of Agricultural \& Biology, 5, 773-776.

Mammen, D., \& Daniel, M. (20I2). A critical evaluation on the reliability of two aluminum chloride chelation methods for quantification of flavonoids. Food Chemistry, 135, I365|368. doi:10.1016/j.foodchem.2012.05.109

Mateo, R., \& Bosch-Reig, F. (1997). Sugar profiles of Spanish unifloral honeys. Food Chemistry, 60, 33-4I.

Meda, A., Lamien, C.E., Romito, M., Millogo, J., \& Nacoulma, O.G. (2005). Determination of the total phenolic, flavonoid and proline contents in Burkina Fasan honey, as well as their radical scavenging activity. Food Chemistry, 91, $57 \mathrm{I}-577$

Mendes, E., Proença, E.B., Ferreira, I.M.P.L.V.O., \& Ferreira, M.A. (1998). Quality of evaluation of Portuguese honey. Carbohydrate Polymers, 37, 219.

Miguel, M.G., Nunes, S., Dandlen, S.A., Cavaco, A.M., \& Antunes, M.D. (2010). Phenols and antioxidant activity of hydro-alcoholic extracts of propolis from Algarve, South of Portugal. Food and Chemical Toxicology, 48, 34I8-3423.

Moussa, A., Saad, A., \& Noureddine, D. (20I2). How honey acts as an antioxidant? Medicinal and Aromatic Plants, I, el2I. doi: $10.4172 / 2167-0412.1000 \mathrm{e} / 21$

Naab, O.A., Tamame, M.A., \& Caccavari, M.A. (2008). Palynological and physicochemical characteristics of three unifloral honey types from central Argentina. Spanish Journal of Agricultural Research, 6, 566-576. 
Nassif, F., \& El Amiri, B. (20II). Goat production systems in a mountainous community of the Middle Atlas, Morocco. Options Méditerranéennes. Séries A. Mediterranean Seminars, 100, 199-203.

NP-4405:2002. (2002). Microbiologia Alimentar - Regras gerais para a contagem de microrganismos. Contagem de colónias a $30{ }^{\circ} \mathrm{C}$ [Food Microbiology - General rules for counting microorganisms. Colony count at $30^{\circ} \mathrm{C}$ ]. Lisbon: Portuguese Institute of Quality.

Pękal, A., \& Pyrzynska, K. (2014). Evaluation of aluminum complexation reaction for flavonoid content assay. Food Analytical Methods, 7, 1776-1782. doi:I0.1007/s I2I6I-0|4-98I4-x

Peltier, J. (1983). Ecologie de quelques especes climaciques dans le sous (Maroc Occidental) [Ecology of some climactic species in the Sous (Occidental Morocco)]. Documents de Cartographie Ecologique [Ecological Cartography], 26, 6I-82.

Persano Oddo, L., Piro, R., Ivanov, T., Piškulová, J., Flamini, C., Lheritier, J., ... Gotsiou, P. (2004). Main European unifloral honeys: Descriptive sheets. Apidologie, 35(Suppl. I), S38-S8I.

Piana, M.L., Persano Oddo, L., Bentabol, A., Bruneau, E., Bogdanov, S., \& Guyot Declerck, C. (2004). Sensory analysis applied to honey: State of the art. Apidologie, 35(Suppl. I), S26-S37.

Proposal COM/95/0722. (1996, August 9). Proposal for a COUNCIL DIRECTIVE relating to honey/*COM/95/0722 FINAL - CNS 96/0II4 */, Official Journal C23I, p. 0010. Retrieved August 09, 1996, from http://eur-lex.europa.eu/ legal-content/EN/TXT/?qid = | 4807 | | 367909\&uri=CELEX: 51995PC0722(03)

Samatha, T., Shyamsundarachary, R., Srinivas, P., \& Swang, N.R. (20I2). Quantification of total phenolic and total flavonoid contents in extracts of Oroxylum indicum L. Kurz. Asian Journal of Pharmaceutical and Clinical Research, 5, I77-179.
Sancho, M.T., Pascual-Maté, A., Rodríguez-Morales, E.G., Osés, S.M., Escriche, I., Periche, Á., \& Fernández-Muiño, M.A (20I6). Critical assessment of antioxidant-related parameters of honey. International Journal of Food Science \& Technology, 5I, 30-36.

Shin, H.-S., \& Ustunol, Z. (2005). Carbohydrate composition of honey from different floral sources and their influence on growth of selected intestinal bacteria: An in vitro comparison. Food Research International, 38, 721-728.

Singleton, V.L., \& Rossi, Jr., J.A. (1965). Colorimetry of total phenolics with phosphomolybdic-phosphotungstic acid reagents. American Journal of Enology and Viticulture, 16, 144-158.

Soares, J.R.A.S. (1996). Constituição polifenólica e actividade antioxidante de extractos de Thymus zygis [Polyphenolic composition and antioxidant activity of Thymus zygis extracts] (Master's thesis). Universidade de Coimbra, Coimbra.

Sousa, J.M., de Souza, E.V., Marques, G., Meireles, B., de Magalhães Cordeiro, Â.T., Gullón, B., Pintado, M.M., \& Magnani, M. (2016). Polyphenolic profile and antioxidant and antibacterial activities of monofloral honeys produced by Meliponini in the Brazilian semiarid region. Food Research International, 84, 61-68.

Truzzi, C., Annibaldi, A., Illuminati, S., Finale, C., \& Scarponi, G. (20I4). Determination of proline in honey: Comparison between official methods, optimization and validation of the analytical methodology. Food Chemistry, 150, 477-48I.

Von Der Ohe, W., Persano Oddo, L., Piana, M.L., Morlot, M., \& Martin, P. (2004). Harmonized methods of melissopalynology. Apidologie, 35, S18-S25.

Wu, H.C., Shiau, C.Y., Chen, H.M., \& Chiou, T.K. (2003). Antioxidant activities of carnosine, anserine, some free amino acids and their combination. Journal of Food and Drug Analysis, II, I48-I53. 